\title{
Coronavirus pandemic and its impacts on the world's economy
}

\author{
Muhammad Suleman Nasir ${ }^{1}$, Muhammad Qayyum Ahsan ${ }^{2}$ \\ Gomal University, Dera Ismail Khan, Pakistan ${ }^{1}$ \\ Lahore University of Management Sciences (LUMS), Lahore, Pakistan ${ }^{2}$ \\ msuln2222@gmail.com ${ }^{1}$,muhammad.qayyum@lums.edu.pk ${ }^{2}$
}

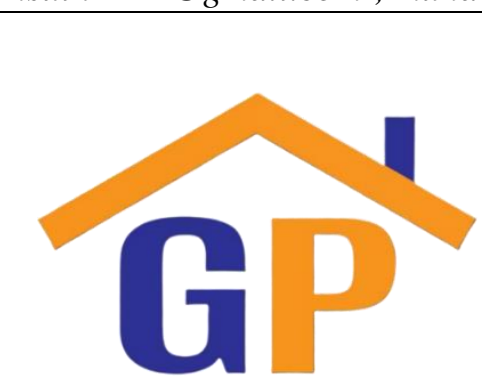

Article History

Received on 13 February 2021

Revised on 2 March 2021

Accepted on 18 March 2021

\begin{abstract}
Purpose: This study is about the coronavirus pandemic and its long-lasting impacts on the world economy. The study's main purpose is to highlight the adverse effects of the Coronavirus on the world's economy and how to mitigate it.
\end{abstract}

Research Methodology: An analytical and descriptive research methodology was conducted to get findings and recommendations. Original material is obtained from primary sources. Information is also taken from books on websites and previous articles on the subject.

Results: Precautions and impacts are presented, followed by the recommendations to diminish the effects of Coronavirus.

Limitations: The impacts of Coronavirus are not limited to developing countries, but this study has given less focus to developed countries.

Contribution: This study is helpful to understand the impacts and redefine the course of actions accordingly.

Keywords: Covid-19, Symptoms, Precautions, Economic effect

How to cite: Nasir, M. S., \& Ahsan, M. Q. (2020). Coronavirus pandemic and its impacts on the world's economy. Journal of Sustainable Tourism and Entrepreneurship, 321-331.

\section{Introduction}

Almost all the countries in the world are currently infected with the Coronavirus. The number of affected people is increasing day by day from China to the United States. China has almost overcome the epidemic, but it is spreading rapidly in other countries. Therefore, on 30 January 2020, WHO declared the Coronavirus a "pandemic" after declaring a global emergency. Due to the lockdown, transportation is severely restricted in more than 100 countries. Demand for petroleum products has fallen sharply due to people being confined to their homes. As a result, petrol prices are hitting a 21year low. The coronavirus outbreak has severely affected the aviation industry as well as tourism. Historical and recreational sites, museums, restaurants, and hotels have all been closed and people associated with them have lost their jobs. As of the end of April, approximately 4.5 million people in the United States were unemployed. The situation is not much different in other countries. The economic situation around the sphere is greatly affected by the Covid-19 pandemic. Most of the countries are trying their best to get rid of the pandemic. For this purpose, they are giving financial packages to the people to cope with the situation. China is the first country to recover from the Coronavirus's effects and its economy is growing faster than ever. The global economy is in dire straits due to the Coronavirus Pandemic, but China is gaining record. The People of the Republic of China gained more than 75 billion in foreign trade last month in November 2020, breaking its decades-old record. (Dw.com/Urdu, 2020)

\section{Research methodology}

An analytical and descriptive research methodology will be conducted to get findings and recommendations. Original material is obtained from primary sources. Information is also taken from books on websites and previous articles on the subject. Following the findings and recommendations 
of this study, it is hoped that this will help reduce the risk of Coronavirus in the world and support the economy of the affected countries

\section{Discussions}

\subsection{Coronavirus (Covid-19)}

The Coronavirus was first introduced in 1960. In the later part of 1960, a group of virologists named, McIntosh, Becker, \& Chanock(1967) and others under the administration of Tyrell were examining distinctive strains of human and creature infections which included mouse hepatitis infection, irresistible bronchitis infection, transmissible gastroenteritis infection of swine, etc. all of them were morphologically same as illustrated by electron infinitesimal ponder. Thus, a brand new genus of viruses was found, which was named Corona, where the term Corona indicated the crown-like appearance of the surface within the morphological structure of infections. In 1965, Tyrell \& Bynoe ML (1966) separated, to begin with human Coronavirus within the year 1965 from the respiratory tract of a patient with complaint of the common cold. WHO (2020) officials state that there are many types of the Coronavirus. So far, 13 types have been discovered, of which seven types can be transmitted from animals to humans and can be fatal to humans. They cause fever and severe respiratory problems. The Coronavirus is transmitted from mammals and birds to humans. It is a type of influenza that is transmitted through the nose to the lungs.

The Coronavirus is a large family that infects animals and humans. The Coronavirus causes respiratory infections in humans such as MERS and SARS." The most newly discovered Coronavirus that causes the disease is Covid- 19. Ksiazek et al (2003) described that Coronavirus attacks are not usually dangerous, but they were extremely dangerous in the case of the SARS-CoV and MERS-CoV epidemics.", and according to De Groot et al, (2013) it has caused "SARS-CoV and MERS-CoV". It has produced more than 10,000 total cases in the last two decades with a mortality rate of $10 \%$ for SARS-CoV and 37\% for MERS-CoV by WHO (2003) and WHO (2019) respectively. The most newly discovered Coronavirus that causes the disease is Covid-19. The virus, dubbed the 2019 novel Corona, was first reported by the WHO on 31 December 2019. The genetic code for this new virus is known to be similar to that of Respiratory Syndrome (SARS). Humans have fought even more serious diseases before the Coronavirus. In Europe in the 14th century, a plague killed 200 million people. This disease, called Black Death, was transmitted from rats to humans. A century ago, the Spanish flu pandemic affected 500 million people, of whom 50 million died. The disease was bird flu, meaning the virus that caused the disease was transmitted from birds to humans. The Coronavirus is definitely a dangerous virus.

MimirBook (2020) explained that the word virus literally means "poisonous" in Latin. A virus is a small infectious agent that replicates only inside the living cells of an organism. They can affect all types of life, from animals and plants to microorganisms, including bacteria and arachnids. Viruses are found in almost every ecosystem on Earth. The study of viruses is a sub-feature of microbiology known as virology. Coronaviruses belong to many viruses that cause illness ranging from mild cold to severe diseases. "It is a new virus known as SARS coronavirus-2 and "the disease caused by it has been named Covid-19. This was discovered in China at the end of 2019." Nuhu (2020) explained that the Coronavirus is a large family that infects animals and humans. When viewed under a microscope, the hemispherical virus's edges showed a bulge that usually formed a crown-like shape. Because in Latin the crown is called krona. That is why they are called coronaviruses. "In humans, the Coronavirus causes respiratory infections. The Coronavirus consists of an undivided RNA aperture enclosed in a membrane. Richman et al (2016) has the view that it is said to be part of a genus of bacteria (Coronaviridae) that is commonly found in humans and animals. Coronaviruses have a chain of RNA and they cannot multiply until they enter living cells and gain control over their functions. Only the tip of it helps to enter the cells. The virus infects other cells and continues to do so. Such viruses are commonly found in animals such as cattle, pets, and wildlife, such as bats. When transmitted to humans, they can cause fever, respiratory diseases, and inflammation of the lungs. People who have a weakened immune system, i.e., the elderly and patients with various diseases, are more disposed to it. 


\subsection{How Coronavirus spread}

Chinese scientists have claimed, after genetic research that for the first time, a new type of the Coronavirus has been spread by snakes that were placed with live bats in a market in Wuhan. Soup and food of snakes, insects, and bats are common in China. Experts in other countries believe that the virus, as in the past, is spread by animals that are sold alive near fruits and vegetables in Chinese markets, and so did the SARS. It is not yet known how the deadly Coronavirus spread from animals to humans. Some scientists attribute the spread of the virus to bats because they are experts in spreading the virus far and wide. According to Professor Kate Jones of University College London," there is evidence that bats have become accustomed to long and tiring flight and are capable of repairing DNA damage on their own. Since then, she has been able to cope with the many viruses in her body, but this is still an idea described in googlynews (2020)." According to BBC (2020), Jonathan Ball, a professor at the University of Nottingham, says that "if you look at the lifestyle of bats, there is no doubt that they grow viruses and because they are mammals, they can transmit the virus directly or indirectly to human but it is not yet known through which animal the virus was transmitted to humans. Because in China, pangolins and other wildlife, such as bats, are often sold in wet markets (markets where live animals are kept in the water) that can spread the virus from one animal to another. Is more Animals and humans are more likely to spread the virus in such markets. The markets sell wolf cubs, golden locusts, scorpions, rats, squirrels, foxes, leopards, owls, turtles, and alligators, as well as fish and camels, bears, dogs, and other animals. Where live and slaughtered animals are sold. Therefore, experts say that all the viruses we have discovered in recent years have been transmitted from wildlife to humans, whether it is Ebola or SARS, and now the Coronavirus. In a report published in the medical journal General of Medical Virology by Wei Ji, Wei Wang and others (2002), Chinese researchers suggested that the snake could be the cause of the spread of the 2019 novel Coronavirus. For this purpose, they analyzed the genetic code of the virus and compared it to two types of snakes, the Chinese cobra, and the banded krait. According to researchers, there are many similarities between the genetic code of snakes and this virus. After the study, two other research reports by Peng Zhou et al (2020) rejected the claim that live bats spread the virus. A group of Chinese scientists said they compared the virus's genetic code to earlier SARS coronaviruses and other bat coronaviruses and discovered genetic similarities between them. "The virus has infected $80 \%$ of its genes in the past and shares $96 \%$ of coronaviruses found in bats. Most importantly, research has shown that the virus can enter and control cells in the same way that SARS does."

Some scientists have suspected that the Coronavirus could be spread through the manure of a type of bat, Guano Bat. In a village in Thailand, people gather guano bats. This bat is demanded by the farmers here for use in fertilizer. Scientists suspect that the fertilizer may be the cause of the deadly Coronavirus. Numerous scientists believe the virus has been transmitted to humans by bats, while residents of the village that collected the bats say they have never had health problems in such a long time. Cidrap News (2002) reported that according to Infectious Diseases Research and Policy at the University of Minnesota, "health workers in China have been infected with the virus. This was a significant point in the SARS epidemic outbreak as health workers spread the disease from one country to another. The Chinese authorities confirmed the virus to medical staff and indicated that it had been transmitted from person to person-And scientists say the biggest threat could be the spread of the epidemic in hospitals, which was also seen in the SARS and MERS coronaviruses, so the action is needed." In Dawn News (2020) Report, "The Chinese government has also indicated that the virus could be transmitted from person to person before symptoms appear, as symptoms do not appear for one to 14 days before the disease appears and by then the patient will be self-sufficient, considers healthy". That is why it is spreading so fast.

The basic biological information about the Coronavirus is not yet known, which animals caused it to be transmitted to humans, and currently, snakes and bats are thought to be its main cause. For people infected with the virus, the particles coming out of their mouths and noses that accumulate on things around them are transmitted to other people. Many people may have mild symptoms in the initial phases of the illness. This can spread the virus. Most animals, such as pigs and chickens, are still infected, but the virus has changed its form and affects humans. Because humans inadvertently touch 
their bodies, including touching the mouth, nose, and eyes, and the habit of touching regularly is dangerous. This habit is causing the spread of the Coronavirus (Covid-19) Pandemic. Therefore, any joint crockery and utensils should be thoroughly cleaned after use, and the bathroom and shared surfaces should also be thoroughly cleaned. However, someone can still catch the virus from an infected person, if they contaminate surfaces, such as changing clothes or building door handles. An infected person can spread the virus through coughing and sneezing if they come in close contact with others. When healthy people shake hands or hug a patient with the Coronavirus, the virus enters the human body through the hands and breath. Medical experts say the virus spreads rapidly from one person to another. Therefore, medical personnel treating patients with the virus also have to take rigorous precautions.

\subsection{How contagious is the Coronavirus?}

It is well known that every type of virus is contagious, but how contagious is it? This is usually done with the help of a decimal system (RO value) for the basic reproductive number, meaning that the value indicates how many people a person with the disease can make sick in the future. The Varicella RO number is 12 to 18, while the SARS epidemic was rated RO3 in 2002 and 2003. Various research reports have given a value of 1.4 to 3.8 for COVD-19 presented by Jonathan et al (2020), and this is currently a preliminary estimate. However, with the speed at which it is spreading, it is not difficult to predict that its RO value may increase. Eric Feigl Ding, an epidemiologist at Harvard University, gave it a value of 3.8 in a tweet on 20 January, 2002. Scientists are still in the early stages of understanding the disease and its spreading and research reports are currently informative and cannot be finalized. Scientists believe the disease has the potential to be transmitted from one person to another. Nevertheless, so far, no evidence has emerged that the new Coronavirus symptoms are similar to those of the Coronavirus that spread the disease in the past.

\subsection{Effects of the virus on the body}

The Coronavirus attacks the body when someone inhales or by touching the things which an infected person used. The virus first infects the throat then other organs of the body. In the early stages, the person does not get sick with it and most people do not show any symptoms of the disease. The duration of the infection and the onset of symptoms vary during the care period, but it is an average of five days.

\subsection{Symptoms of Coronavirus}

Coronavirus 2019 is a new disease. According to the information so far, most patients have the same symptoms during the disease. The symptoms of the Coronavirus are similar to those of the common flu. The Coronavirus's early symptoms may include fever, cough, cold, body aches, sore throat, headache, and difficulty breathing. The Coronavirus attacks the body when someone inhales or by touching the things which an infected person used. It identifies the virus as a troublesome invader and sends a single substance called cytokines throughout the body that causes something to go wrong. This triggers the body's immune system. The Coronavirus initially causes a dry cough (no mucus). Some people eventually develop a thick mucus-like substance, which includes cells that die from the virus. Symptoms such as a runny nose and runny nose have been reported in some patients, while the runny nose and coughing up mucus are not common symptoms. If the disease worsens, the patient may develop pneumonia. And if pneumonia worsens, the patient may die, so such patients are isolated to confirm the virus. Early symptoms of Corona include pneumonia and swelling of the lungs, making it difficult for the patient to breathe. Many people suffer from it but do not show any symptoms. About $80 \%$ of people do not need any medical attention. One in six patients has serious symptoms and difficulty breathing. Especially older people who have other diseases are more affected. $\mathrm{BBC}$ (2021) reporters Lora Jones, Daniele Palumbo \& David Brown, highlighted that, "The period between the entry of the virus into the body and the appearance of symptoms is called the incubation period." Chaolin et al (2020), in their article about an analysis of the coronary artery and the clinical features of the resulting disease stated that, "Patients with the virus have symptoms such as fever, high body temperature, fatigue or muscle aches, difficulty breathing, coughing up 
mucus or blood, headache, cholera, and dry cough." As the disease progresses, it takes the form of pneumonia",published in the medical journal, The Laurent, on 24 January 2019. It is observed that, the period from infection to the beginning of signs is 14 days but some scientists say it can be up to 24 days.

\subsection{Prevention and precautions}

Precautionary measures are being taken worldwide following the hundreds of deaths from the Coronavirus in various countries. The Coronavirus is definitely a dangerous virus; Effective precautions are needed to avoid this. Some precautionary measures are described below.

1. Regularly washing hands removes the virus that accumulates on the hands. Performing ablution five times a day is very helpful in preventing all kinds of infections.

2. Stay about three feet away from people who show symptoms of respiratory illnesses such as coughs and sneezes.

3. Follow coughing and sneezing etiquette and teach others. Cover your mouth with your elbow when coughing and sneezing. This will prevent the drops from spreading in the air.

4. Wash your hands thoroughly before and after cooking. Cook food thoroughly. Avoid raw or poorly cooked food and use boiled water.

5. Stay away from pets and avoid touching them. Do not touch the mouth, eyes, and nose with dirty hands. We use our hands to touch. When carried on the face, the virus particles on the hands are more likely to enter the body.

6. Because it is a viral disease, people with the virus should avoid using antibiotics. Antibiotics work in bacterial infections. They cause further complications in viral infections.

7. The virus is present on the patient's used items for a long time. Therefore, it is important to avoid the use of used items by people infected with the virus.

8. Although masks are not a means of protection against the virus, people with the flu virus must use handkerchiefs and masks so that other people are not infected. Wearing a mask or veil (Niqab) can also reduce the habit of touching the face in people, which is a major cause of the spread of infection. Wear a mask when going out.

9. To prevent Coronavirus, it is as important to keep your hands motionless as it is to wash them. 10. The Coronavirus is spread from person to person when a person's nose or mouth is sprayed with the virus and spread to others. But the epidemic also occurs when we touch something or a surface on which the virus is already present, so take special care to clean things that are often touched.

11. Identify and test suspects, treat and quarantine-Quarantine refers to "medical detention" in which the patient is kept in a separate area for fourteen days or more to confirm the virus's presence or absence.

12. BBC News health team urges people to be careful about the epidemic-If someone needs to buy a bargain, use the online service. In the meantime, you should try to stay away from your pets and if this is not possible, wash your hands before and after going to them. Anyone suspected of having the Coronavirus should have minimal contact with others in the home. If possible, they should not be in the same room.

13. The highest risk of Coronavirus is in people who are weak or who already have health problems or who are addicted to smoking. The virus has caused as many deaths as ever. The vast majority of elderly people are smokers who already have a disease. People who are older and have a weakened immune system and those who already have health problems such as diabetes Have asthma or heart disease, they will feel more effects and symptoms of Coronavirus. The most important thing for such a patient is not to be afraid. If people have a fever or cough, they are more likely to get the flu, not the Coronavirus. These people need to be more careful than other people. People who smoke should avoid or reduce smoking. People with other illnesses should continue their daily medication and not leave home unnecessarily.

\subsection{Effects of Coronavirus on world's economy}

A significant economic crisis erupted in the United States in October 1929. It is known in history as the Great Depression. The crisis engulfed rich and poor countries alike. Industries shut down, 
investors' savings and economic growth and prosperity became a thing of the past. The worldwide unemployment rate has exceeded 33\%. As a result, three million people lost their jobs in the UK alone, six million in Germany, and 14 million in the United States.

\section{World economies struggling with rising unemployment}

Yeariy unemployment rate change, 2019-2020

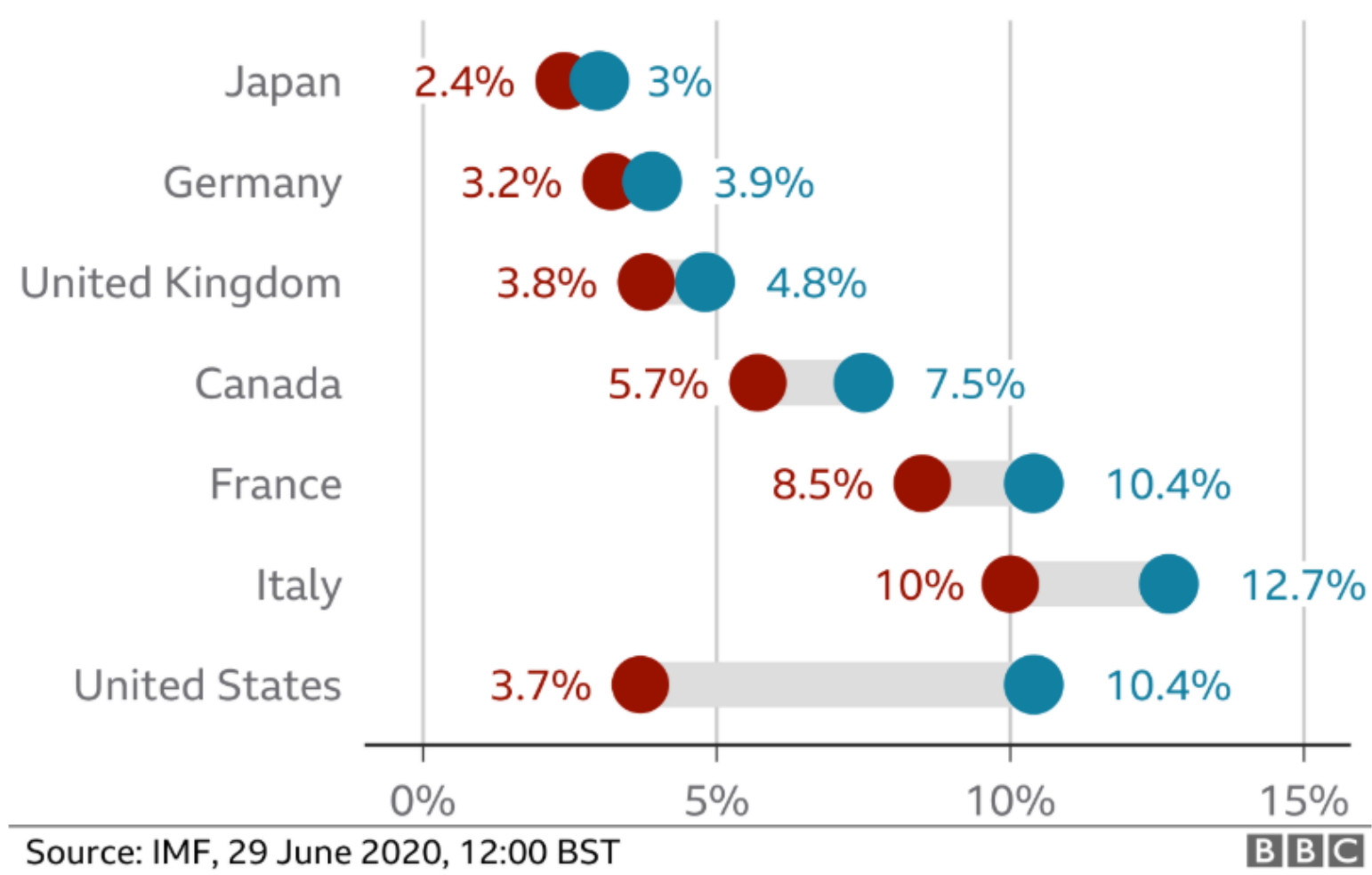

Figure 1. World economies struggling with raising unemployment (IMF, as cited in Jones et al., 2021)

The proportion of people out of work has hit $10.4 \%$ in USA and France and $12.7 \%$ at Italy. Due to the economic turmoil, the total volume of world trade fell by more than $50 \%$. The rising cost of food, the uncertainty of the situation, and the constant worries have forced many people to commit suicide. The crisis was so severe that by 1932, every notable bank in the United States had closed. The Great Depression lasted for four years in 1933. During this period, the impoverished people in the world in general and in Europe and Latin America in particular incited internal strife and instability through a series of strikes and riots. As a result, the administrative and political landscape in many countries has changed dramatically. Adolf Hitler, the leader of the Nazi Party in Germany, took advantage of these dire circumstances to wrap up the rug of democracy in 1933 and pave the way for his dictatorial rule. The Coronavirus began to spread around the world in early 2020. Initially, people's attitude towards precautionary measures was superficial and frivolous. However, as the virus intensified and its lethal effects became apparent, various countries took strict security measures. Prolonged lockdowns around the world have shut down millions of companies, and millions have lost their jobs, temporarily or permanently.The IMF warned that the current year's global economy will face up to a $3 \%$ deficit. That's why economists have expressed concern, that the time to come in view of the economic difficulties and the current situation may refresh the horrible memories of the Great Depression. According to a recent report, if the lockdown in the UK continues for another two to three months, the 
British economy will suffer a decline that is unprecedented in the last three centuries. For the first time since 1987, the coronavirus pandemic has caused world's stock markets to plunge.

\section{The impact of coronavirus on stock markets since the start of the outbreak}

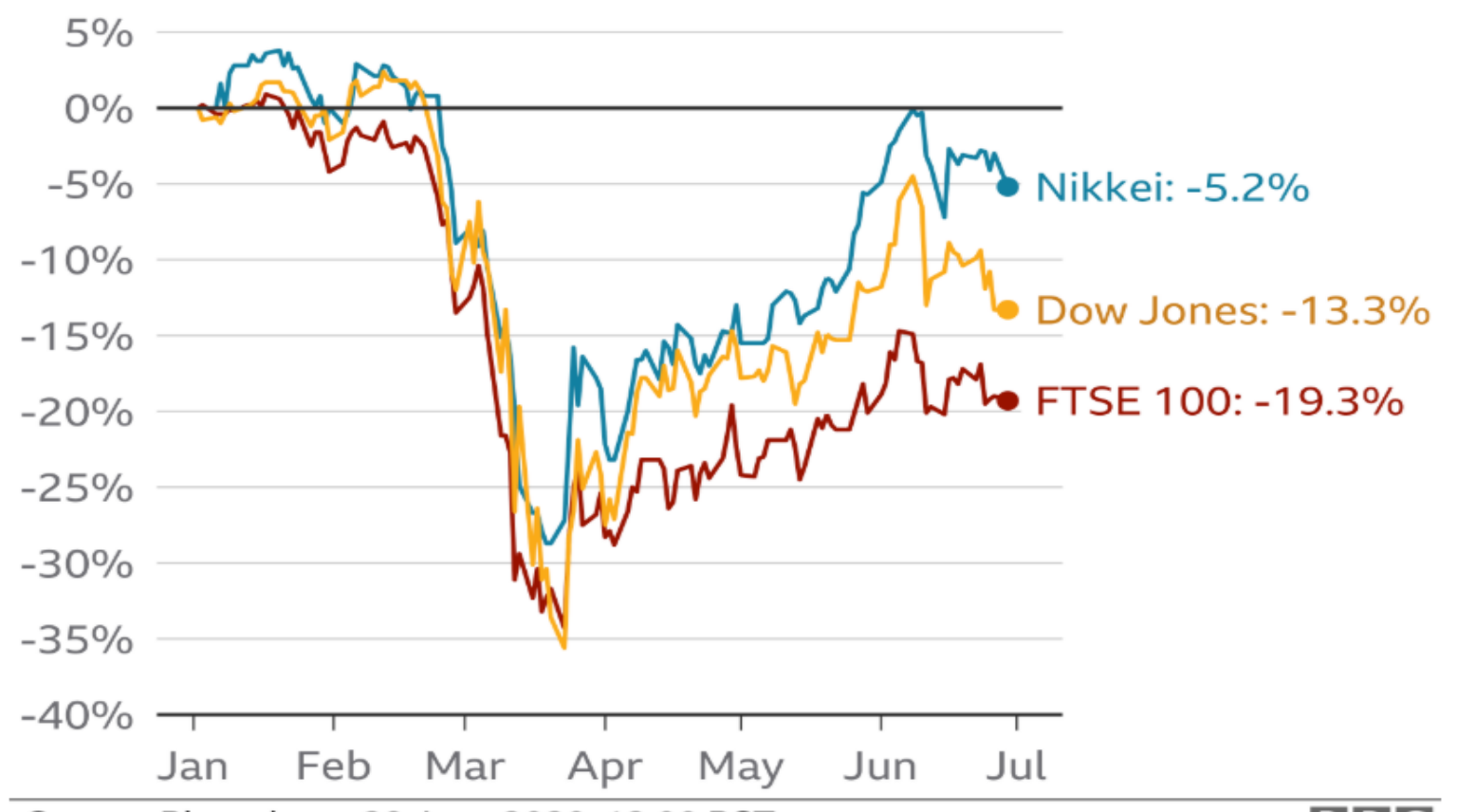

Source: Bloomberg, 29 June 2020, 12:00 BST

$\mathrm{B}|\mathrm{B}| \mathrm{C}$

Figure 2. The impact of Coronavirus on stock markets since the start of the outbreak (Bloomberg, as cited in Jones et al., 2021)

In the United States, interest rates have been reduced to zero, promoting investment and providing employment to the people and making them financially comfortable. Due to the lockdown, unnecessary transportation is severely restricted in more than 150 countries. Demand for petroleum products has fallen sharply due to people being confined to their homes. As a result, petrol prices are hitting a 21-year low. The coronavirus outbreak has severely affected the aviation industry as well as tourism. The existing historical and recreational places, museums, restaurants, and hotels are all closed and the people associated with them are useless. As of the end of May, about 5 million people in the United States were unemployed. The situation is not much different in other countries. Under normal circumstances, the unemployment rate in Western countries is low. Most people are busy with their work. It's just a holiday when they spend time with their spouse or family members. The current situation has put people in Europe and the United States in another dilemma with unemployment, and that is domestic strife and incompetence. Most people are addicted to alcohol and luxury. It is not their habit to accumulate wealth. As a result of not having a permanent source of livelihood, their lives have become unbearable due to anxiety and restlessness.

In light of the statistics, it is clear that the rate and scope of the spread of the Coronavirus varies from country to country. According to economists, the current outbreak of the Coronavirus will be the biggest cause of the economic crisis since World War II. The question is not whether the economic crisis will come or not, the question is how long it will last and how deep it will go and hollow out the economy of any country. The financial damage of the Coronavirus began in January 2020. The pandemic, which broke out in China, dealt a severe shock to the supply of worldwide merchandise and raw ingredients. Many global conferences and expos have had to be canceled or deferred because 
of the virus being spread from one person to another. The Coronavirus is estimated to cost the global economy at least 6 trillion dollars. Many industries are near to collapse. Except for a few businesses, every business is in crisis and their economy dropped from $30 \%$ to $95 \%$.

\section{Majority of countries on the brink of recession Real GDP growth, Q1 2020}

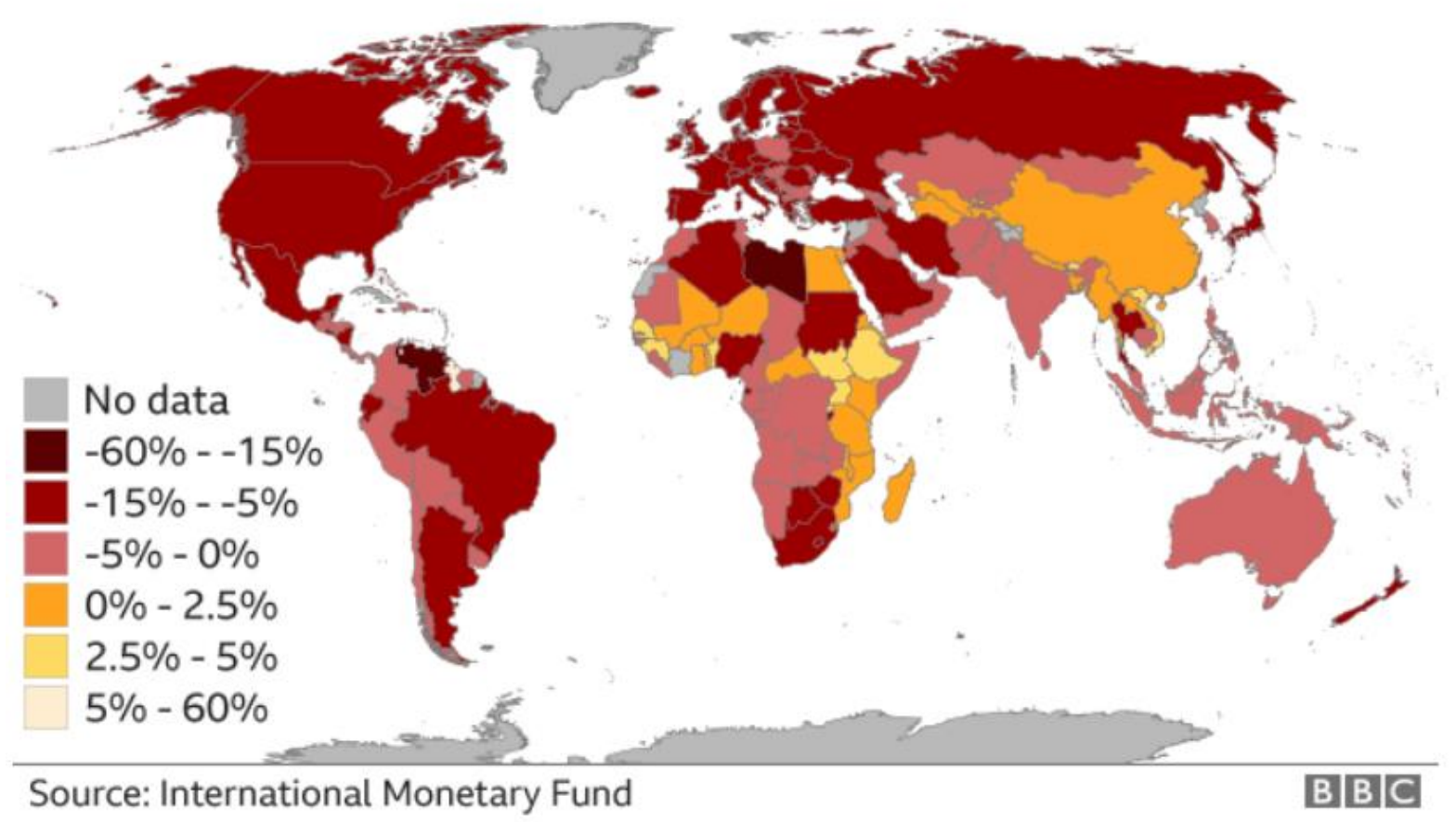

Figure 3. Majority of countries on the brink of recession (IMF, as cited in Jones et al., 2021)

These businesses included the Airlines, restaurants, transport business, rental car and entertainment, and film industry. Stock markets around the world are suffering. Due to low consumption, Crude oil prices have fallen and many businesses were closed. Some businesses that rely on online businesses have multiplied a lot. The coronavirus pandemic has profoundly affected the global economy. In the last ten years, various developments have taken place in the global economy. In the year 2008, the whole world had to face a financial crisis. After more than ten years, the world system has deteriorated rather than improved. The economic situation began to deteriorate again. And in recent years, a trade war between China and the United States has begun to threaten the global economy, raising expectations of a new global crisis.

BBC Urdu writes that the Corona epidemic is signaling a severe crisis beyond expectations and appearances and has left the future of the global economy in a state of gradual uncertainty. "The Oxfam charity warns that the economic effects of the Coronavirus could add up to half a billion in world poverty. Citing research from the Australian National University and King's College London, Oxfam said it would be the first time in 30 years to increase global poverty. According to the report, the economic crisis due to the conditions caused by the virus will be more severe than the medical crisis and global poverty will increase significantly." The World Bank has said that given the global outbreak of the Coronavirus, it is not possible to avert economic hardships. At the same time, 24 million people around the world, including many Asian countries, will not be able to get out of poverty. 
The first and foremost effects of the Coronavirus are undoubtedly being felt in the global economy. Undoubtedly, the most significant effects of this deadly disease on how long it will last and how long it can be controlled are being felt in the global economy. Uncertainty over how long this deadly disease will continue, how long it will be under control, the damage it will do to human health, and whether or not to re-emerge will begin to weigh heavily on the global economy. The effects of which we are all beginning to feel.

China's reversal of growth rates, stagnation in some Chinese production sectors, and stagnation in leading European economies such as Italy, France, Germany and Spain have forced the United States to take action. Despite a hefty 700 billion bailout of the Coronavirus by the US Federal Reserve, its impact on financial markets is almost non-existent. Kent Rigov, who also serves as a top adviser to global economic organizations such as the IMF, has claimed that the global economy will fall into recession as it recedes. The Oxford Research Institute has announced that countries with foreign debt will face difficulties in repaying their debts.

On the other hand, the US Federal Reserve will pursue non-implementation fiscal expansion policies. France has announced that it will use a staggering 500 billion euros in measures against Corona. These measures to reduce the Coronavirus effects are unable to slow down the economic stagnation as the global economy is now approaching stagnation. If the situation continues at this level, then it seems that the improvement in the global economy will not be possible for the next two years. This situation could lead to a problematic international situation and lead to countries' bankruptcy with critical economic conditions. Therefore, the Corona epidemic may require developing a new structure for the global economy, rather than pushing the global economy into a crisis.

\section{Findings}

*Coronavirus is a contiguous disease. Its symptoms are simple. Prevention is better than cure, so one should not be afraid of it but to fight it.

*The world is witnessing a sharp decline in economic performance due to the Coronavirus pandemic.

*Developing countries have been hit hard by the recession.

*The world's largest companies are facing a severe financial crisis.

* Many countries export industrial raw materials. The closure of many factories worldwide has reduced the demand for the commodity, so their prices have fallen, and in some cases, this decline is very high. Oil is the biggest example of this. Oil demand has fallen sharply as the Coronavirus lockdown has reduced fuel demand for transportation. More than $90 \%$ of this fuel is made from crude oil. Apart from oil, copper prices have also come down. The fall in prices is affecting businesses and the revenues of governments that export these goods-

*Developing countries also face the problem of money being withdrawn by foreign investors. Investors are investing in relatively safe countries, rather than in developing countries. As a result, these countries' currency prices have fallen, which has led to an increase in their foreign debt. Developing countries also face declining remittances. Remittances are often sent from rich countries to poor countries and can support a family's standard of living.

\section{Conclusion}

Before the Coronavirus, the world has encountered many other pandemics that have damaged the world's economy. The Spanish flu in 1918, affected most of the European countries, and the SARS and MERS affected the Middle East countries. The 1918 flu affected a quarter of the world's population at the time, killing 50 million people. At that time there was only a system of trains or ships, for 2 years the world was stuck in this monster. However, the virus did not reach parts of northern Alaska and Copenhagen, the capital of Denmark. The world has remained the same since the 
Spanish flu of 1918, and there is still hope for the best. The recent Coronavirus pandemic which started in December 2019 has not yet stopped. Due to the pandemic, the world's economy is shrinking. The developing countries are facing many difficulties for the revival of their economy. Although the developed countries announced huge economic packages to cope with the pandemic situation. Troubles, sudden disasters, and epidemics are a test for human beings.

The American Civil War of 1887 united the whole country. After the Spanish flu of 1918, the National Health Service NHS was founded in Europe. Institutions such as the Social Welfare State and Social Security were strengthened after World War II. Afghanistan releases Taliban prisoners after Coronavirus and the path to a ceasefire was paved in Yemen. In light of the statistics, it is clear that the rate and scope of the spread of the Coronavirus varies from country to country. So precautionary measures should be abided at all cost. Allah Almighty knows best how long the world will get rid of this pandemic. We hope that the world will be better off after this pandemic.

\section{Recommendations}

In order to solve the debt and health problems in developing countries, it is necessary to take the following steps.

1. All necessary measures should be taken to avoid the coronavirus pandemic. People's health should be the first priority for any country; therefore the precautionary measures should be strictly implemented.

2. The IMF and the world's leading economies should forgive the debts of developing countries, cut interest rates on these loans so that these countries can get some relief.

3. Deferring loans alone do not work. Therefore, the IMF, G20, and others should do more in this regard and the repayment of loans should be canceled completely.

4. Developed countries should not fire workers from poor countries to not face remittance shortage in their country.

5. Countries that have overcome the epidemic should share their experiences with countries where the epidemic has not yet been brought under control.

6. Foreign investors should not transfer capital from the stock exchanges of developing countries to other countries so that these countries can be protected from further losses.

\section{References}

BBC Urdu. (2021). Corona virus: Economic damage threatens to add half a billion people to global poverty. https://www.bbc.com/urdu/world-52226233 (accessed, 15 February, 2021)

Chaolin Huang, MD., Yeming Wang, MD., Xingwang Li, MD., Lili Ren., Jianping Zhao, MD., \& Yi Hu, MD. (2020), Clinical features of patients infected with 2019 Novel Coronavirus in Wuhan, China. The Lancet, 395(10227), 497-506.

Cidrap News. (2020). New-coronavirus-infects-health-workers-spreads-korea, ,http://www.cidrap.umn.edu/news perspective/2020/01/new-coronavirus-infects-healthworkers-spreads-korea,(accessed,10 Jan, 2020).

Corona ki Taqat Mazeed Barrah Gai. (2020), https://www.dawnnews.tv/news/1119175/. (accessed, 26, Jan, 2020.)

Corona virus: Where did the corona virus start. (2020). https://www.bbc.com/urdu/science-51632070 (accessed, 21 January, 2020)

de Groot, R. J., Baker, S. C., Baric, R. S., Brown, C. S., Drosten, C., Enjuanes, L., Fouchier, R. A., Galiano, M., Gorbalenya, A. E., Memish, Z. A., Perlman, S., Poon, L. L., Snijder, E. J., Stephens, G. M., Woo, P. C., Zaki, A. M., Zambon, M., \& Ziebuhr, J. (2013). Middle East respiratory syndrome coronavirus (MERS-CoV): announcement of the Coronavirus Study Group. Journal of virology, 87(14), 7790-7792.

GooglyNews. (2020). Where did the Corona Virus start? The final answer could not be found. https://googlynews.tv/45525,(accessed, 20 January, 2020)

IMF (29 June, 2020). World economies struggling with rising unemployment. International Monetary Fund, Washington DC. 
Ji, W., Wang, W., Zhao, X., Zai, J., \& Li, X. (2020). Cross-species transmission of the newly identified coronavirus 2019-nCoV. Journal of medical virology, 92(4), 433-440.

Jonathan M Read., Jessica RE Bridgen., Derek AT Cummings., Antonia Ho., Chris P Jewel. (2020). Novel Coronavirus 2019-Ncov: early estimation of epidemiological parameters and epidemic predictions. doi: https://doi.org/10.1101/2020.01.23.20018549

Jones, L., Palumbo, D., \& Brown, D. (2021). Coronavirus: How the pandemic has changed the world economy. BBC News. https://www.bbc.com/news/business-51706225.

Ksiazek TG, Erdman D, Goldsmith CS, Zaki SR, Peret T, Emery S, Tong S, Urbani C, Comer JA, Lim W, Rollin PE, Dowell SF, Ling AE, Humphrey CD, Shieh WJ, Guarner J, Paddock CD, Rota P, Fields B, DeRisi J, Yang JY, Cox N, Hughes JM, LeDuc JW, Bellini WJ, Anderson LJ; SARS Working Group. (2003) A novel coronavirus associated with severe acute respiratory syndrome. The New England Journal of Medicine, 348(20), 1953-1966.

McIntosh, K., Kapikian, A. Z., Hardison, K. A., Hartley, J. W., \& Chanock, R. M. (1969). Antigenic relationships among the coronaviruses of man and between human and animal coronaviruses. Journal of Immunology (Baltimore, Md. : 1950), 102(5), 1109-1118.

MimirBook. (2020). Virus (RNA Virus, Virus). https://mimirbook.com/ur/ccac44ce3bf (accessed, 12 January, 2020)

Nuhu, A. S. (2020). The corelation between Covid-19 confirmed and recovered cases in China: simple regression linear model evidence. Electronic Research Journal of Social Sciences and Humanities, 2(1).

Richman, D. D., Whitley, R. J., Hayden, F. G., eds. (2016). Clinical Virology, 4th edn. Washington: ASM Press.

Tyrrell D. A., \& Bynoe M. L. (1966). Cultivation of viruses from a high proportion of patients with colds. Lancet, 1, 76-77.

WHO. (Dec 31, 2003). Summary of probable SARS cases with onset of illness from 1 November 2002 to 31 July 2003". https://www. who.int/csr/sars/country/table2004_04_21/en/ (accessed Jan 19, 2020)

WHO. (November, 2019). Middle East Respiratory Syndrome Coronavirus (MERS-CoV)." http://www.who.int/emergencies/mers-cov/en/ (accessed 19 ${ }^{\text {January }}, 2020$ )

WHO. Novel-Coronavirus-China. (12 January, 2020), https://www.who.int/csr/don/12-january-2020novel-coronavirus-china/en/ (accessed, 21 March, 2020).

Zhou, P., Yang, X. L., Wang, X. G., Hu, B., Zhang, L., Zhang, W., ... \& Shi, Z. L. (2020). A pneumonia outbreak associated with a new coronavirus of probable bat origin. nature, 579(7798), 270-273. 